\title{
A protective role for lymphocytes in cyclophosphamide- induced endogenous bacteraemia in mice
}

\author{
YOICHI HIRAKATA*, NOBUHIKO FURUYA, KAZUHIRO TATEDA and KEIZO YAMAGUCHI
}

Department of Microbiology, Toho University School of Medicine, Tokyo 143, Japan

\begin{abstract}
Summary. Cyclophosphamide (CY) is used in many animal studies, including models of bacteraemia, to deplete peripheral neutrophils and induce a compromised state. Although $\mathrm{CY}$ also influences lymphocyte function, the protective role of lymphocytes in bacteraemia is unclear. Therefore, $\mathrm{CY}(200 \mathrm{mg} / \mathrm{kg})$ was administered to ddY mice and its influence on the number, cellular composition, and function of lymphocytes in the spleen and Peyer's patches was examined. A single dose of CY reduced the number of lymphocytes in a time-dependent fashion. Flow cytometry showed that B cells carrying B220 antigen decreased significantly. The production of IgA in Peyer's patches, as measured by enzyme-linked immunosorbent assay, was also suppressed in a time-dependent fashion. Blastogenic responses of splenic lymphocytes to Concanavalin-A, lipopolysaccharide and heat-killed Pseudomonas aeruginosa were suppressed $48 \mathrm{~h}$ after $\mathrm{CY}$ administration. The results suggest that $\mathrm{CY}$ suppresses the number and function of lymphocytes, especially B cells. This may lead to bacterial overgrowth in the gut and result in bacteraemia. Intravenous transfusion of normal lymphocytes or oral inoculation of IgA to mice with $P$. aeruginosa D4 endogenous bacteraemia significantly increased survival rates, indicating that lymphocytes and their products have a protective role in bacteraemia in mice.
\end{abstract}

\section{Introduction}

Septicaemia in immunocompromised patients frequently arises as a result of invasion by endogenous microflora, particularly from the gastrointestinal tract. ${ }^{1-3}$ Pseudomonas aeruginosa is a typical cause of endogenous bacteraemia originating in the intestinal flora $^{2-4}$ and is associated with high mortality rates. ${ }^{5-7}$

We reported previously that $P$. aeruginosa causes a high mortality rate in leucopenic mice with endogenous bacteraemia induced by cyclophosphamide $(\mathrm{CY}){ }^{8}$ We also established a model of endogenous bacteraemia induced by feeding specific $P$. aeruginos $a$ strains to mice treated with $\mathrm{CY} .{ }^{9-12}$ This model includes important steps involved in the infection process, such as bacterial colonisation, overgrowth in the intestinal tract, invasion into the bloodstream, production of virulence factors and death. Consequently, the pathological features of bacteraemia in this model are similar to those of septicaemia in human patients..$^{10,13}$

Received 1 Sept. 1994; revised version received 14 Nov. 1994; accepted 26 Jan. 1995.

*Present address and address for correspondence: Department of Pulmonary Medicine, Jichi Medical School, 3311-1 Minami Kawachi, Tochigi 329-04, Japan.
In many animal studies, CY is used to reduce and deplete peripheral neutrophils and induce a compromised state. ${ }^{9-17} \mathrm{CY}$ also affects lymphocyte function, such as delayed-type hypersensitivity ${ }^{18,19}$ and is selectively toxic to B cells. ${ }^{20,21}$ However, the role of lymphocytes in protection against bacteraemia is not fully understood. CY was administered to mice and its influence on the number, cellular composition, and function of lymphocytes from the spleen and Peyer's patches was examined. Subsequently, normal T or B splenic lymphocytes were introduced into mice with $P$. aeruginosa D4 endogenous bacteraemia and their survival was compared with that of control mice to establish the protective role of lymphocytes. Finally, the influence of oral administration of purified murine IgA on the mortality of mice was examined with the same model.

\section{Materials and methods}

\section{Animals}

Specific-pathogen-free (SPF) male ddY mice (Japan SLC Co., Shizuoka) weighing 20-24 g were used in the present experiments. BALB/c, BALB/c nu/nu and BALB/c nu/ + (Japan SLC) mice weighing 18-22 g were also used. Mice were fed a sterile diet and received 
sterile distilled water except during the period of oral administration of the bacteria.

\section{Spleen and Pever's patch cells}

The numbers of spleen and Peyer's patch cells were examined at set time intervals after a single administration of CY (Endoxan; Shionogi Co. Ltd, Osaka, Japan) $200 \mathrm{mg} / \mathrm{kg}$ by intraperitoneal injection. Mice were anaesthetised by ether inhalation and the femoral vein was cut to exsanguinate the animals. The spleen and Peyer's patches were removed and teased with frosted glass in RPMI 1640. The suspension was passed through sterile gauze. Red blood cells in the spleen were lysed with $0.16 \mathrm{M}$ ammonium chloride in Tris buffer. The resultant cells were washed twice with RPMI 1640, diluted in Turke's solution and counted by microscopy.

\section{FACS analysis}

Spleen and Peyer's patch cells were prepared as described above, adjusted to $1.0 \times 10^{7}$ cells $/ \mathrm{ml}$ and stained with fluorescein isothiocyanate (FITC)-conjugated anti-CD3 monoclonal antibody (MAb) (PharMingen, CA) or phycoerythrin (PE)-conjugated anti-B220 MAb (PharMingen) for $30 \mathrm{~min}$ at room temperature. After duplicate washing with Hanks's Balanced Salts Solution, cells were fixed with paraformaldehyde $1 \%$. Labelled cells were washed again and analysed with a flow cytometer (FACStar; Becton Dickinson. CA. USA).

\section{Blastogenic response of spleen cells}

Spleen cells were obtained aseptically from ddY mice as described above. The cells were suspended at a density of $1.0 \times 10^{6}$ cells $/ \mathrm{ml}$ in RPMI 1640 containing fetal calf serum $10 \%$ penicillin $100 \mathrm{U} / \mathrm{m}$, streptomycin $100 \mu \mathrm{g} / \mathrm{ml}$, and 2-mercaptoethanol $\left(1.0 \times 10^{4} \mathrm{M}\right) ; 50 \mu \mathrm{l}$ of cell suspension were transferred ( 5000 cells/well) to flat-bottomed 96-well tissue culture plates. Spleen cells were incubated for $72 \mathrm{~h}$ in the presence or absence of Concanavalin-A (Con-A, Sigma) $5 \mu \mathrm{g} / \mathrm{ml}$, lipopolysaccharide (LPS) from Escherichia coli (Difco) $25 \mu \mathrm{g} / \mathrm{ml}$ or heat killed $P$. aeruginosa D4 $10^{5}$ cells $/ \mathrm{ml}$. Cultures were pulsed with $0.5 \mu \mathrm{Ci}$ of $\left[\right.$ methyl $-{ }^{3} \mathrm{H}$ ] thymidine/well for the final $18 \mathrm{~h}$ of incubation. Cells were then collected with an automatic cell microharvester. [Methyl ${ }^{3} \mathrm{H}$ ] thymidine incorporation was measured in a scintillation counter (Matrix 96; Packard Instrument Company, CT, USA).$^{22}$ All specimens were run in triplicate and the mean result was used.

\section{Quantification of $\operatorname{IgA}$}

Peyer's patch cells were incubated for $72 \mathrm{~h}$ in RPMI 1640 containing fetal calf serum $10 \%$, penicillin $100 \mathrm{U} / \mathrm{ml}$, streptomycin $100 \mu \mathrm{g} / \mathrm{ml}$ at a concentration of 100 cells $/ \mathrm{ml}$ at $37^{\circ} \mathrm{C}$ in $\mathrm{CO}_{2} 5 \%$. The culture supernate was passed though a $0 \cdot 22-\mu \mathrm{m}$ microfilter. The level of IgA in the filtrate was measured with an enzyme-linked immunosorbent assay (ELISA) with goat anti-murine IgA antibody (E-Y Laboratories Inc., CA, USA) and peroxidase-conjugated rabbit anti-murine IgA antibody (Zymed Laboratories Inc., CA, USA). Purified rabbit IgA (Zymed) was used as a standard.

\section{Experimental design of endogenous bacteraemia}

Endogenous $P$. aeruginosa bacteraemia was produced as described previously. ${ }^{9}$ Briefly, $P$. aeruginosa D4 was isolated from cardiac blood of a mouse with systemic endogenous bacteraemia induced by $\mathrm{CY}{ }^{8}$ Bacteria were suspended in sterile saline $0.45 \%$ and adjusted to a suitable concentration for each experiment by optical density (UVIDEC-40 spectrophotometer, Tokyo, Japan). Faecal specimens were obtained before the study and examined to ensure the absence of $P$. aeruginosa. Mice were fed $P$. aeruginosa D4 in drinking water between days 1 and 4. They also received sodium ampicillin (Viccillin; Meiji Seika Kaisya Co. Ltd, Tokyo, Japan) $200 \mathrm{mg} / \mathrm{kg}$ during this period to disrupt the normal gastrointestinal flora. On days 5 and 8 , CY $200 \mathrm{mg} / \mathrm{kg}$ /day was administered. Mice were observed four times daily and deaths were recorded up to day 15 . Specimens of cardiac blood were obtained immediately from dead mice and mice were killed at the end of the experiment. All samples were cultured aerobically on Trypticase Soy Agar (BBL Microbiology Systems, Cockeysville, MD,

Table. Influence of CY on number of spleen and Peyer's patch cells

\begin{tabular}{ccc}
\hline $\begin{array}{c}\text { Time after } \\
\text { CY } \\
\text { administration } \\
(200 \mathrm{mg} / \mathrm{kg})\end{array}$ & $\begin{array}{c}\text { Number }\left(\times 10^{\overline{7}} / \text { mouse }\right) \\
(\%) \text { of spleen cells }\end{array}$ & $\begin{array}{c}\text { Number }\left(\times 10^{5} / \text { mouse }\right) \\
(\%) \text { of Peyer's patch cells }\end{array}$ \\
\hline $\begin{array}{c}\text { Control } \\
6 \mathrm{~h}\end{array}$ & $4.18 \mathrm{SEM} 2.35(100)$ & 7.47 SEM $3.17(100)$ \\
$12 \mathrm{~h}$ & 2.17 SEM $1.63(51.9)$ & 5.67 SEM $1.53(75.9)$ \\
$24 \mathrm{~h}$ & 1.96 SEM $1.41(46.9)$ & 4.80 SEM $1.48(64.3)$ \\
$48 \mathrm{~h}$ & 1.41 SEM $0.74^{*}(33.7)$ & 4.80 SEM $1.96(64.3)$ \\
& 1.03 SEM $0.98^{*}(24.6)$ & 2.00 SEM $0.49^{*}(26.8)$ \\
\hline
\end{tabular}

*Significantly lower than control value $(\mathrm{p}<0.01)$ 


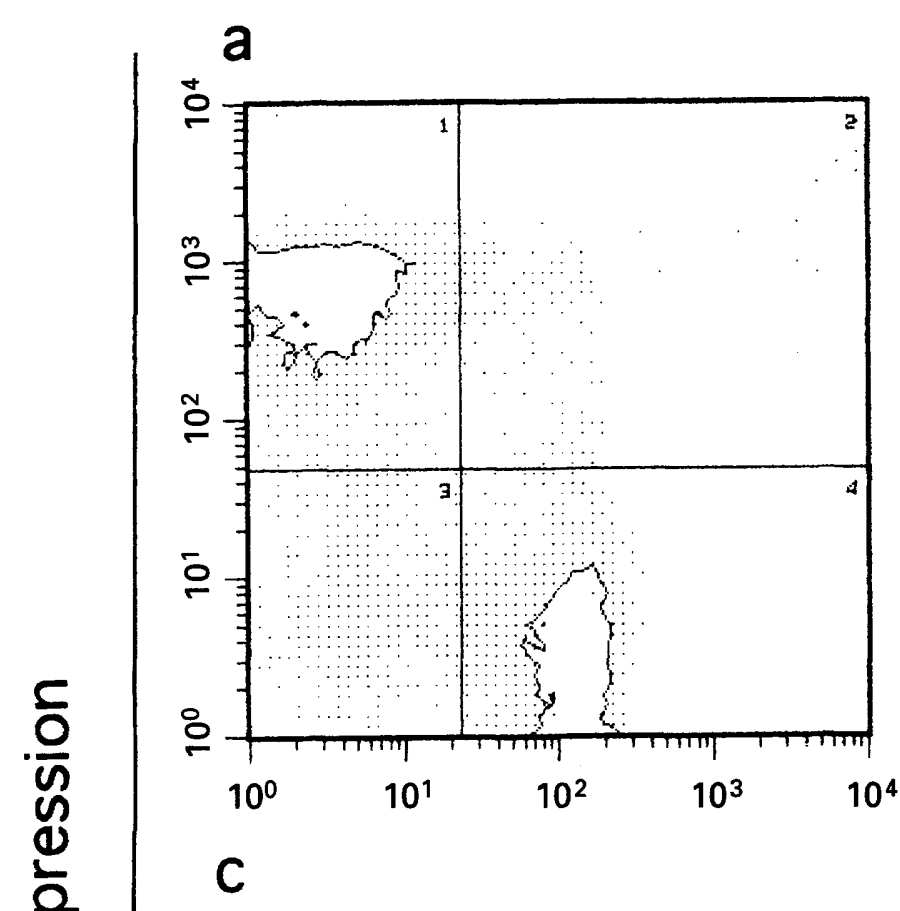

b
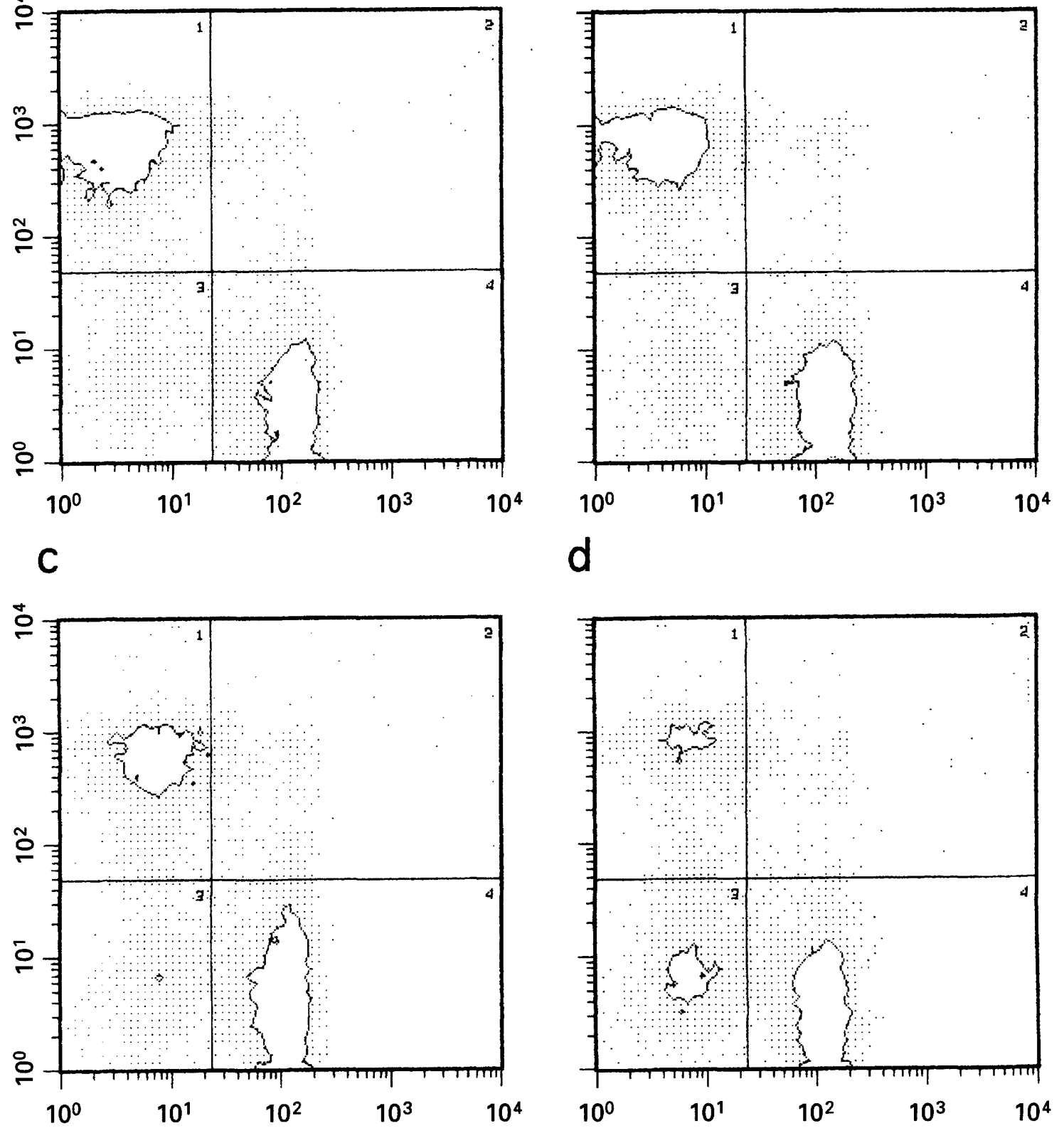

\section{3 expression}

Fig. 1. Two-colour FACS analysis of spleen cells from mice with or without administration of CY. CD3 and B220 antigens were stained with FITC- and PE-labelled MAbs, as markers of T and B cells, respectively. Note the time-dependent decrease in B cells (B220 $0^{+}$cells). a, Control; b, $\mathbf{c}$ and $\mathrm{d}, 12,24$ and $48 \mathrm{~h}$ after administration of $\mathrm{CY}$.

USA) at $37^{\circ} \mathrm{C}$ in humidified air for $24 \mathrm{~h}$ and examined for the presence of $P$. aeruginosa.

\section{Effect of lymphocyte transfusion on survival rates of} mice with endogenous $P$. aeruginosa bacteraemia

Spleen cells obtained from BALB/c nu/nu and $\mathrm{BALB} / \mathrm{c} \mathrm{nu} /+$ were used as B and $T$ cell sources, respectively. A single cell suspension was obtained as described above. Cells were adjusted to a concentration of $1 \times 10^{6}$ cells $/ \mathrm{ml}$ and incubated in plastic dishes at $37^{\circ} \mathrm{C}$ in $\mathrm{CO}_{2} 6 \%$ for $1 \mathrm{~h}$. Non-adherent cells were gathered and washed twice with RPMI 1640. Cells obtained from BALB/c nu/ + mice were passed through a $T$ cell immunocolumn (Cellect Mouse $T$ Cell Kit; Biotex Laboratories Inc., Alberta, Canada) to remove B cells. Over $95 \%$ of cells in preparations obtained from BALB/c nu/nu and $\mathrm{nu} /+$ mice were positive for $\mathrm{B} 220$ and $\mathrm{CD} 3$, respectively. In the endogenous $P$. aeruginosa bacteraemia model with neutropenic BALB $/ \mathrm{c}$ mice, $1 \times 10^{7}$ cells/mouse of T or $B$ cell preparations were transfused into mice intravenously on days 6 and 9 . 


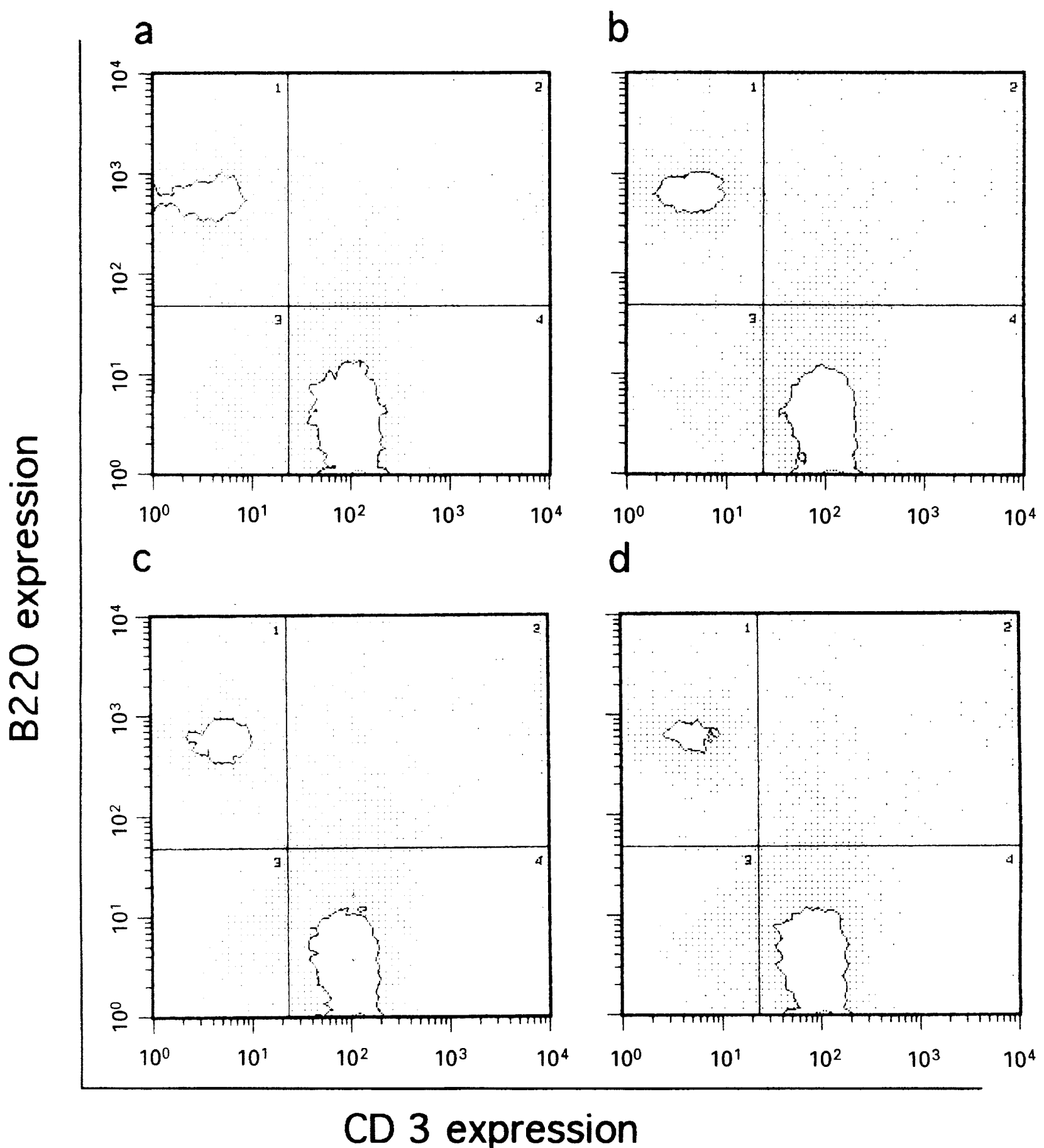

Fig. 2. Two-colour FACS analysis of Peyer's patch cells from mice with or without the administration of CY. Note the time-dependent reduction of $\mathrm{B}$ cells (B220 cells). a, Control; b, c and d. 12, 24 and $48 \mathrm{~h}$ after administration of CY.

Effect of oral inoculation of IgA on survival rate of mice with endogenous $P$. aeruginosa bacteraemia

IgA $5 \mu \mathrm{g} / \mathrm{ml}$ in bovine serum albumin (BSA) $2 \%$ was mixed with drinking water and provided from day 5 until the end of experiment to ddY mice with endogenous $P$. aeruginosa bacteraemia. IgG $5 \mu \mathrm{g} / \mathrm{ml}$ in $\mathrm{BSA} 2 \%$ or BSA only were given as controls.

\section{Statistical methods}

The Student's $t$ test and $\chi^{2}$ test were used to compare means and survival rates, respectively.

\section{Results}

\section{Number of spleen and Peyer's patch cells}

As shown in the table, a single dose of CY reduced the number of spleen and Peyer's patch cells in a timedependent fashion. Spleen cell counts 24 and $48 \mathrm{~h}$ after $\mathrm{CY}$ administration were significantly lower than those of controls $(p<0.01)$. The number of Peyer's patch cells $48 \mathrm{~h}$ after injection of CY was also significantly lower than that of controls $(\mathrm{p}<0 \cdot 01)$. 


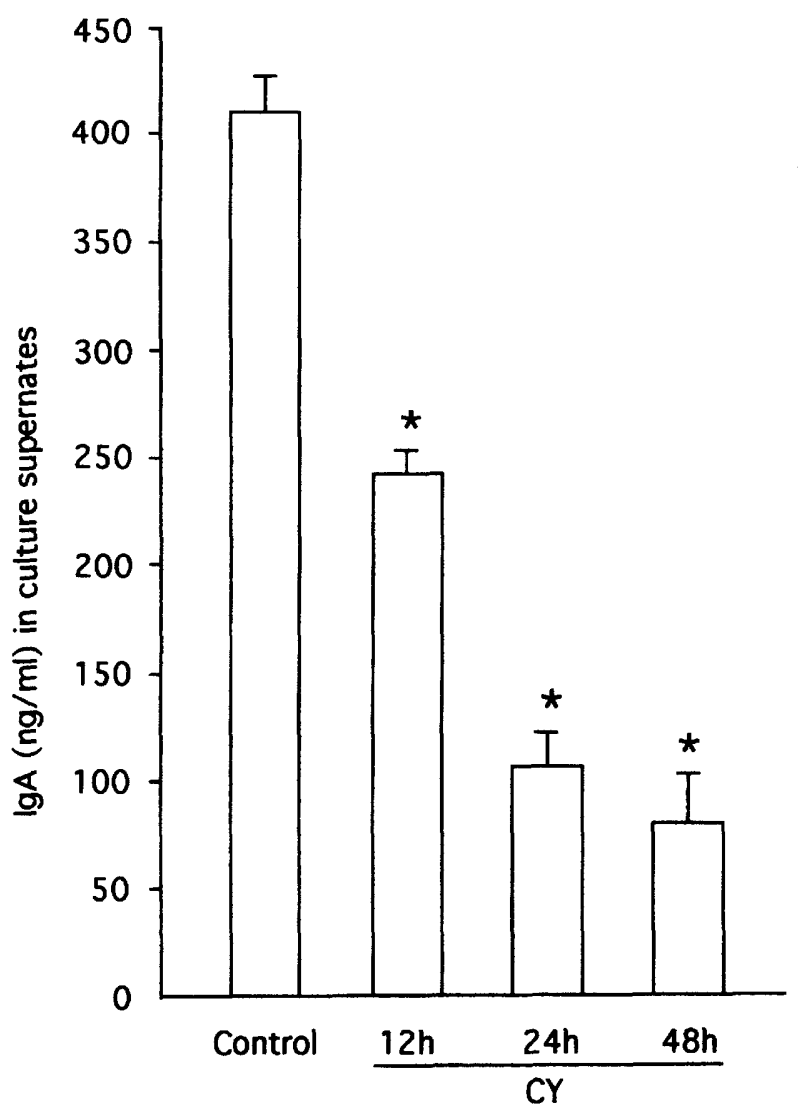

Fig. 3. IgA production by Peyer's patch cells from mice with or without the administration of $\mathrm{CY} ;{ }^{*} \mathrm{p}<0.01$.

\section{FACS analysis}

A single dose of $\mathrm{CY}$ reduced $\mathrm{B} 220^{+}$cells in the spleen progressively with time (fig. 1). In control mice, $\mathrm{B}_{22} 0^{+}, \mathrm{CD}^{-}$cells comprised $48.9 \%$ of the total cell count. The values were $40 \cdot 1,29 \cdot 2$ and $16 \cdot 2 \%$ at 12,24 and $48 \mathrm{~h}$, respectively, after administration of CY. In contrast, $\mathrm{CD}^{+}, \mathrm{B} 220^{-}$spleen cells increased from $42.5 \%$ in control to $68.3 \% 48 \mathrm{~h}$ after CY injection. No change occurred in $\mathrm{CD} 4^{+}$cells and $\mathrm{CD} 8^{+}$cells (data not shown). Similar results were obtained in Peyer's patches as shown in fig. 2.

\section{Blastogenic response}

Spleen cells obtained from control mice showed a high blastogenic response against Con-A, $E$. coli LPS and heat-killed $P$. aeruginosa D4. The mean ${ }^{3} \mathrm{H}$ thymidine incorporation was 42088 SEM 26600 Matrix CPM when stimulated with Con-A $5 \mu \mathrm{g} / \mathrm{ml}$. The values were 11523 SEM 1694 and 2695 SEM 309 CPM, when stimulated with LPS $25 \mu \mathrm{g} / \mathrm{ml}$ and heat-killed $P$. aeruginos $a \mathrm{D} 4,10^{8}$ cells $/ \mathrm{ml}$, respectively. The count without stimulation was 1075 SEM 157 CPM. Spleen cells treated with CY showed almost no response against such stimulation. The counts were 34 SEM 9, 21 SEM 6 and 24 SEM 6 CPM when

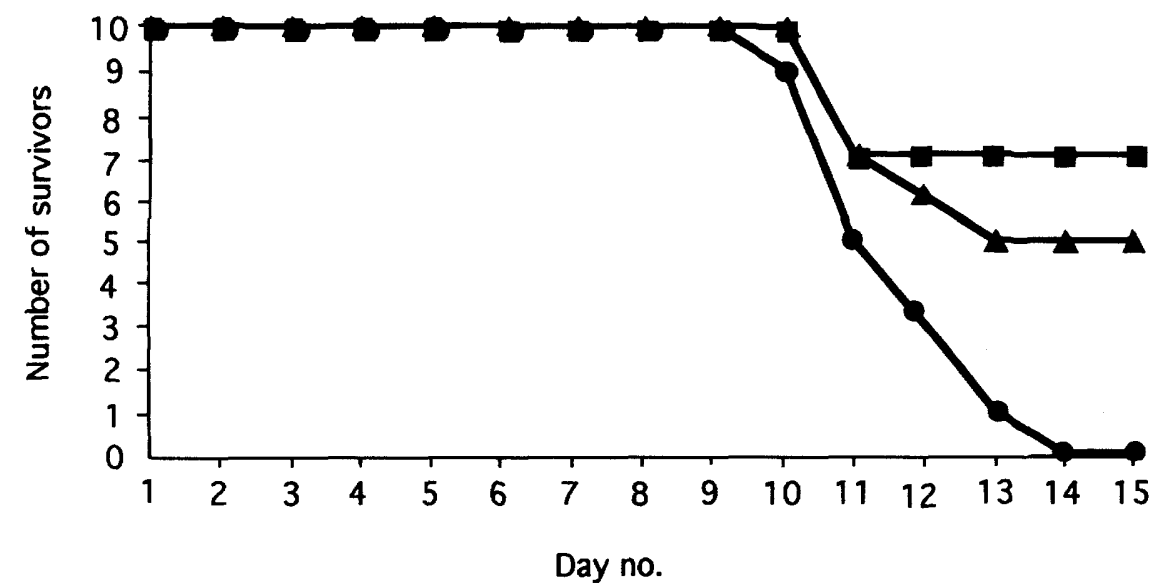

Fig. 4. Effect of lymphocyte transfusion on survival of mice with $P$. aeruginosa endogenous bacteraemia : $-\square$, B cell transfusion, $\mathrm{p}<0 \cdot 01$; $\Delta-\boldsymbol{\Delta}$, T cell transfusion, $\mathrm{p}<0.06 ;-\mathbf{O}$, control.

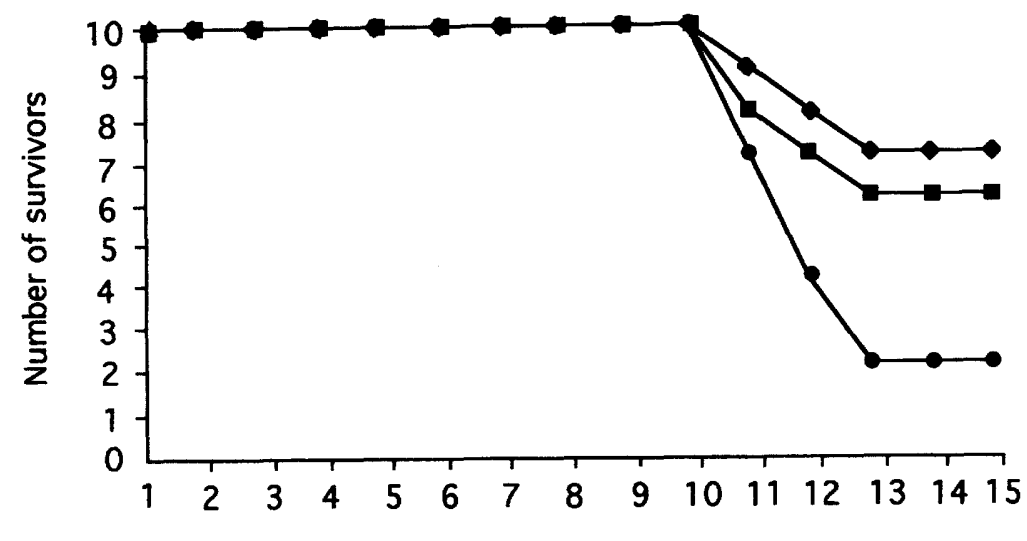

Day no.

Fig. 5. Effect of oral administration of IgA or IgG on survival rates or mice with endogenous $P$. aeruginosa bacteraemia: (BSA); - $\longrightarrow$ IgA, p < 0.05; $-\mathbf{\square}$, IgG (NS). 
lymphocytes from mice treated with $C Y$ stimulated with Con-A, LPS and heat-killed $P$. aeruginosa D4, respectively.

\section{$\operatorname{Ig} A$ production}

The concentration of $\operatorname{IgA}$ in the culture supernate of Peyer's patch cells obtained from CY-treated mice significantly decreased in a time-dependent fashion $(\mathrm{p}<0.01$ at any time interval after administration of CY). Control cells produced 407.9 SEM $8 \cdot 1 \mathrm{ng} / \mathrm{ml}$ of $\operatorname{IgA}$ compared with 105.0 SEM $8.3 \mathrm{ng} / \mathrm{ml} 24 \mathrm{~h}$ after the administration of $\mathrm{CY}$ (fig. 3 ).

\section{Effect of lymphocyte transfusion on survival rates of mice with endogenous $P$. aeruginosa bacteraemia}

As shown in fig. 4, transfusion of B cells obtained from the spleen of BALB/c nu/nu mice significantly protected BALB/c mice against a lethal endogenous $P$. aeruginosa septicaemia $(70 \%$ survival rate, $\mathrm{p}<$ $0.01)$. Transfusion of $\mathrm{T}$ cells also increased survival rate from $0 \%$ to $50 \%(\mathrm{p}<0.06)$. Pure cultures of $P$. aeruginosa were obtained from cardiac blood samples of all mice that died of septicaemia. By contrast, blood cultures were sterile in all survivors at the end of the experiment.

\section{Effect of oral inoculation of IgA on survival rates of mice with endogenous $P$. aeruginosa bacteraemia}

Continuous oral inoculation of IgA significantly increased the survival rate of mice from $20 \%$ to $70 \%$ $(p<0.05)$ (fig. 5). IgG also increased survival rate of mice $(60 \%)$, although this did not reach statistical significance.

\section{Discussion}

The results of this study showed that a single administration of CY $200 \mathrm{mg} / \mathrm{kg}$ dramatically reduced lymphocyte counts in the spleen and Peyer's patches in a time-dependent fashion. FACS analysis revealed that B cells were predominantly influenced by CY as compared with $\mathrm{T}$ cells. CY also significantly suppressed the blastogenic response of lymphocytes from the spleen to both $\mathrm{T}$ and $\mathrm{B}$ cell mitogens. $\mathrm{CY}$ also significantly decreased IgA production by lymphocytes from Peyer's patches in a time-dependent fashion. IgA is an important product of B cells and plays a primary role in protecting the host against exogenous and endogenous micro-organisms, including bacteria from the digestive tract, ${ }^{23-25}$ It is possible that by suppressing $\mathrm{B}$ cell function and reducing $\operatorname{IgA}$ production, CY suppresses the immunity of the intestinal tract. These results suggest that suppression of the number and function of not only neutrophils but also lymphocytes, particularly B cells, may contribute to the pathogenesis of endogenous bacteraemia arising from the gastrointestinal tract.

These results demonstrate that the transfusion of normal lymphocytes, especially $\mathbf{B}$ cells, protected mice from lethal endogenous $P$. aeruginosa septicaemia. Moreover, oral inoculation of IgA significantly increased the survival rate of mice. These results suggest that lymphocytes play a protective role in endogenous $P$. aeruginosa bacteraemia.

\section{References}

1. Bodey GP. Epidemiological studies of Pseudomonas species in patients with leukemia. Am J Med Sci 1970; 260: 82-89.

2. Schimpff SC. Young VM, Greene WH, Vermeulen GD, Moody MR. Wiernik PH. Origin of infection in acute nonlymphocytic leukemia. Significance of hospital acquisition of potential pathogens. Ann Intern Med 1972; 77: 707-714.

3. Young LS, Stevens P. Kaijser B. Gram-negative pathogens in septicaemic infections. Scand J Infect Dis 1982; Suppl 31: $78-94$.

4. Tancrede $\mathrm{CH}$, Andremont AO. Bacterial translocation and gram-negative bacteremia in patients with hematological malignancies. $J$ Infect Dis $1985 ; 152$ : 99-103.

5. Baltch AL. Griffin PE. Pseudomonas aeruginosa bacteremia: a clinical study of 75 patients. Am J Med Sci 1977: 274: $119-129$

6. Pollack M. Young LS. Protective activity of antibodies to exotoxin $\mathrm{A}$ and lipopolysaccharide at the onset of Pseudomonas aeruginosa septicemia in man. J Clin Invest 1979 63: $276-286$

7. Roberts FJ. Geere IW. Coldman A. A three-year study of positive blood cultures, with emphasis on prognosis. Rev Intect Dis 1991: 13: 3446.

8. Hirakata Y. Tomono K. Tateda K et al. Role of bacterial association with $\mathrm{Kupffer}$ cells in occurrence of endogenous systemic bacteremia. Infect Immun 1991: 59: 289-294.

9. Hirakata Y. Kaku M. Tomono K et al. Efficacy of erythromycin lactobionate for treating Pseudomonas aeruginosa bacteremia in mice. Antimicrob Agents Chemother 1992: 36: 11981203

10. Hirakata Y. Furuya N. Tateda K. Kaku M. Yamaguchi K. In-

vivo production of exotoxin $\mathrm{A}$ and its role in endogenous Pseudomonas aeruginosa septicemia in mice. Infect Immun $1993 ; 61$ : 2468-2473.

11. Furuya N, Hirakata $\mathrm{Y}$, Tomono $\mathrm{K}$ et al. Mortality rates amongst mice with endogenous septicaemia caused by Pseudomonas aeruginosa isolates from various clinical sources. J Med Microbiol 1993; 39: 141-146.

12. Matsumoto T, Kaku M, Furuya $\mathrm{N}$ et al. Amphotericin Binduced resistance to Pseudomonas aeruginosa infection in mice. J Antibiot 1993; 46: 777-784.

13. Collins HH, Cross AS, Dobek A, Opal SM, McClain JB, Sadoff JC. Oral ciprofloxacin and a monoclonal antibody to lipopolysaccharide protect leukopenic rats from lethal infection with Pseudomonas aeruginosa. $J$ Infect Dis 1989 ; 159: 1073-1082.

14. Opal SM, Cross AS, Kelly NM et al. Efficacy of a monoclonal antibody directed against tumor necrosis factor in protecting neutropenic rats from lethal infection with Pseudomonas aeruginosa. J Infect Dis 1990; 161: 1148-1152.

15. Patterson TF, Fothergill AW, Rinaldi MG. Efficacy of itraconazole solution in a rabbit model of invasive aspergillosis. Antimicrob Agents Chemother 1993; 37: 2307-2310.

16. Melissen PMB, van Vianen W, Bakker-Woudenberg IAJM. Treatment of Klebsiella pneumoniae septicemia in normal and leukopenic mice by liposome-encapsulated muramyl tripeptide phosphatidylethanolamide. Antimicrob Agents Chemother 1994; 38: 147-150.

17. Alder J, Mitten M, Jarvis K, Gupta P, Clement J. Efficacy of clarithromycin for treatment of experimental Lyme disease in vivo. Antimicrob Agents Chemother 1993; 37: 1329-1333.

18. Okuyama $\mathrm{H}$, Matsunaga $\mathrm{T}$, Kobayashi $\mathrm{S}$, Hashimoto $\mathrm{Y}$. 
Kawaguchi Y, Yamamoto K. Effect of cyclophosphamide pretreatment on defective delayed-type hypersensitivity in autoimmune-prone MRL mice. Int Arch Allergy Appl Immunol 1989; 88: 394-401.

19. Smith HR, Chused TM, Steinberg AD. Cyclophosphamideinduced changes in the MRL-lpr/lpr mouse: effects upon cellular composition, immune function, and disease. Clin Immunol Immunopathol 1984; 30: 51-61.

20. Zhu LP, Cupps TR, Whalen G, Fauci AS. Selective effects of cyclophosphamide therapy on activation, proliferation, and differentiation of human B cells. J Clin Invest 1987; 79: 1082-1090.

21. Sabbele NR, Van Oudenaren A, Benner R. The effect of cyclophosphamide on B cells and 'background' immunoglobulin-secreting cells in mice. Immunopharmacology $1988 ; 15$ : 21-30.
22. Potter CG, Gotch F, Warne GT, Oestrup J. Lymphocyte proliferation and cytotoxic assays using flat-bed scintillation counting. J Immunol Methods 1987; 105: 171-177.

23. Kobayashi T, Ohmori T, Yanai M, Kawanishi G, Yoshikai Y, Nomoto K. Protective effect of orally administering immune milk on endogenous infection in X-irradiated mice. Agric Biol Chem 1991; 55: 2266-2272.

24. Porter P, Noakes DE, Allen WD. Secretory IgA and antibodies to Escherichia coli in porcine colostrum and milk and their significance in the alimentary tract of the young pig. Immunology 1970; 18: 245-257.

25. Yardley JH, Keren DF, Hamilton SR, Brown GD. Local (immunoglobulin A) immune response by the intestine to cholera toxin and its partial suppression with combined systemic and intra-intestinal immunization. Infect Immun 1978; 19: 589-597. 